\title{
Diterpenes from Erythroxylum barbatum
}

\author{
Cláudio C. dos Santos, ${ }^{a}$ Mary Anne S. Lima, ${ }^{*, a}$ Raimundo Braz, Filho ${ }^{b}$ and Edilberto R. Silveira ${ }^{a}$ \\ ${ }^{a}$ Curso de Pós-Graduação em Química Orgânica, Departamento de Química Orgânica e Inorgânica, \\ Universidade Federal do Ceará, CP 12.200, 60455-760 Fortaleza-CE, Brazil
}

${ }^{b}$ Setor de Química de Produtos Naturais, Universidade Estadual do Norte Fluminense, 28013-600 Campos-RJ, Brazil

\begin{abstract}
Das raízes de Erythroxylum barbatum foram isolados dois novos diterpenos ent- rosan-1-

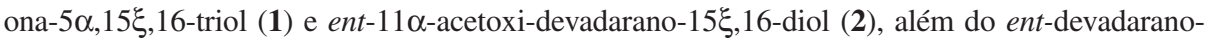

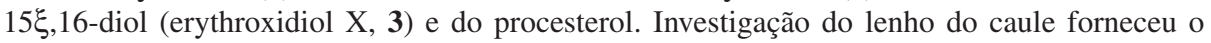
ent-devadarano- $11 \alpha, 15 \xi, 16$-triol (erythroxitriol Q, 4), o ent-devadarano-7 $\beta, 15 \xi, 16$-triol (hidroxidevadarool, 5), o $\beta$-sitosterol e seu glicosídeo. A caracterização estrutural, inclusive a estereoquímica relativa dos compostos, foi estabelecida com base em métodos espectroscópicos, particularmente RMN uni e bidimensional, e comparação com dados da literatura.
\end{abstract}

Two new diterpenes ent-rosan-1-one-5 $\alpha, 15 \xi, 16$-triol (1) and ent-11 $\alpha$-acetoxy-devadarane-

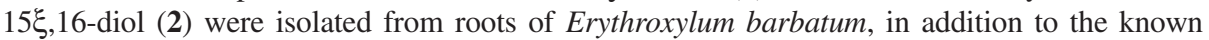

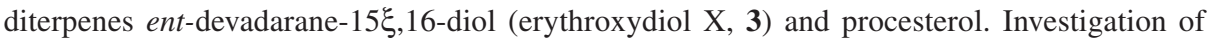
the trunk heartwood furnished the ent-devadarane-11 $\alpha, 15 \xi, 16$-triol (erythroxytriol Q, 4), entdevadarane-7 $\beta, 15 \xi, 16$-triol (hydroxydevadarool, 5), $\beta$-sitosterol and its glucoside. Structural characterization, including the relative stereochemistry of all compounds, was established on the basis of spectroscopic methods, particularly 1D and 2D NMR, and comparison with data from literature.

Keywords: Erythroxylum barbatum, diterpenes, ent-rosan-1-one-5 $\alpha, 15 \xi, 16$-triol, ent-11 $\alpha$-acetoxy-devadarane- $15 \xi, 16$-diol

\section{Introduction}

The genus Erythroxylum comprises 250 species, which are widely distributed throughout the tropics, with large areas of diversity in South America, Africa and Madagascar. This genus is best known as the source of the tropane alkaloids and flavonoids as chemotaxonomic markers, ${ }^{1-4}$ but also as a prolific source of assorted diterpenes..$^{5-7}$ However, with exception of the cocaineproducing species E. coca and E. novogranatense, ${ }^{8}$ few attention has been focused on the phytochemical analysis of this genus and the chemical constituents of many species used in traditional medicine still remain unknown.

Erythroxylum barbatum O. E. Schulz, a small tree endemic to the Northeast of Brazil, is the only species placed by Schulz in the Pogonophorum section of the genus. ${ }^{9}$ Our previous phytochemical investigation on this species revealed the presence of diterpene, prenylated chalcones, pterocarpans, coumarin and steroid, ${ }^{10}$ and a

*e-mail: mary@dqoi.ufc.br more recent report led to the isolation of two kaurene diterpenoids with a unusual skeleton. ${ }^{11}$ This work reports the isolation, from the roots, of the new diterpenes entrosan-1-one-5 $\alpha, 15 \xi, 16$-triol (1) and ent-11- $\alpha$-acetoxy-

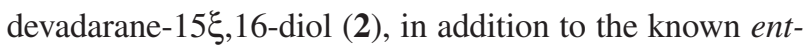

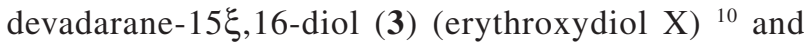
procesterol. Investigation of the trunk heartwood yielded the ent-devadarane-11 $\alpha, 15 \xi, 16$-triol (4) (erythroxytriol Q), ${ }^{12}$ ent-devadarane-7 $\beta, 15 \xi, 16$-triol (5) (hydroxydevadarool), ${ }^{13} \beta$-sitosterol and its glucoside.

\section{Results and Discussion}

Compound $\mathbf{1}$ was isolated as a colorless resin. The IR spectrum showed characteristic absorption of hydroxy group at $3421 \mathrm{~cm}^{-1}$ and keto group at $1708 \mathrm{~cm}^{-1}$.

The ${ }^{1} \mathrm{H}$ NMR spectrum displayed signals for four angular methyl groups [ $\delta_{\mathrm{H}} 1.18(6 \mathrm{H})$ and 1.00 and 0.58$]$. In addition, were observed three carbinolic hydrogens at $\delta_{\mathrm{H}}$ 3.34 (dd, $J$ 9.4, $2.9 \mathrm{~Hz}, \mathrm{H}-15$ ); $\delta_{\mathrm{H}} 3.76$ (dd, $J 10.7,2.9 \mathrm{~Hz}$, $\mathrm{H}-16 \mathrm{a})$ and 3.54 (dd, $J 10.7,9.4 \mathrm{~Hz}, \mathrm{H}-16 \mathrm{~b}$ ) in a typical 
ABC pattern suggesting the presence of a 1,2-glycol system. These observations were further confirmed by the ${ }^{1} \mathrm{H}-{ }^{1} \mathrm{H}$ COSY experiment through the cross-peaks for the geminal coupling of the methylene hydrogens at $\delta_{\mathrm{H}} 3.76$ and 3.54 (2H-16), and for both of them with the hydrogen at $\delta_{\mathrm{H}} 3.34$ (H-15). Further, a spin subsystem constituted by two adjacent methylene hydrogens at $\delta_{\mathrm{H}} 2.39(\mathrm{~m}, \mathrm{H}-2)$ and 1.48 (m, H-3), which were placed between a quaternary carbon and the keto group was characterized.

The ${ }^{13} \mathrm{C}$ NMR spectrum exhibited resonances for four methyl groups, eight methylenes, three methines, and five non-hydrogenated carbons, one of which was associated to a carbonyl group $\left(\delta_{\mathrm{C}} 212.6\right)$.

Pimarane, isopimarane and rosane skeletons have four angular methyl groups and can be differentiated by the relative stereochemistry at C-3 and the position of the methyl at C-20, respectively. Rosanes arise from migration of the $\mathrm{C}-10$ methyl group of pimaranes to the $\mathrm{C}-9$ and occur in both enantiomeric series. The placement of a methyl group at C-9 in a rosane skeleton for compound $\mathbf{1}$ was readily established by detailed examination of the HMBC spectrum, through correlations of the hydrogen at $\delta_{\mathrm{H}} 2.05(\mathrm{H}-10)$ with the methyl group at $\delta_{\mathrm{C}} 11.9(\mathrm{C}-20)$ and the carbon at $\delta_{\mathrm{C}}$ 24.2 (C-6). Furthermore, were observed correlations for the methylene hydrogens at $\delta_{\mathrm{H}} 1.48(\mathrm{H}-3)$ with the carbons at $\delta_{\mathrm{C}} 29.5$ (C-19) and 29.3 (C-18), and of the methylene group at $\delta_{\mathrm{H}} 1.40$ and $1.09(\mathrm{H}-6)$ with the carbons at $\delta_{\mathrm{C}} 62.8(\mathrm{C}-10)$ and $40.2(\mathrm{C}-8)$, respectively. In the same way, correlations of the signal relative to methyl groups at $\delta_{\mathrm{H}} 1.18(\mathrm{H}-18, \mathrm{H}-19)$ and of the hydrogen at $\delta_{\mathrm{H}} 1.70(\mathrm{H}-7)$ with the carbon at $\delta_{\mathrm{C}} 71.2$ (C-5), indicated that the location of the tertiary alcohol at $\mathrm{C}-5$ could be assumed. The position of the carbonyl group at C-1 was deduced by the correlation of its ${ }^{13} \mathrm{C}$ NMR chemical shift at $\delta_{\mathrm{C}} 212.6$ with the hydrogens at $\delta_{\mathrm{H}} 2.39(\mathrm{H}-2)$ and $1.48(\mathrm{H}-3)$. The absolute configuration of $\mathbf{1}$ was not ascertained particularly because its levorotatory property, however, it is reasonable to assume that it possess an absolute stereochemistry belonging to the enantio-series, considering the entrosane skeleton of diterpenoids isolated previously from Erythroxylum species" 5,7 that led to the "Absolute Stereochemistry Biogenetic Rule" suggested by Sukh Dev. ${ }^{14}$ Thus, the structure of $\mathbf{1}$ could be identified as the new ent-rosan-1-one- $5 \alpha, 15 \xi, 16$-triol.

Compound 2, a white amorphous solid, showed a molecular ion at $\mathrm{m} / \mathrm{z} 364$, compatible with a molecular formula $\mathrm{C}_{22} \mathrm{H}_{36} \mathrm{O}_{4}$. The IR spectrum revealed absorption of hydroxyl group at $3456 \mathrm{~cm}^{-1}$, carbonyl ester at 1724 $\mathrm{cm}^{-1}$ and C-O stretching at $1249 \mathrm{~cm}^{-1}$.
The ${ }^{1} \mathrm{H}$ NMR spectrum showed the presence of three methyls groups attached to quaternary carbons at $\delta_{\mathrm{H}} 1.03$ (s, 6H, H-17 and H-18) and 0.94 (s, H-20), associated with the presence of the shielded doublets at $\delta_{\mathrm{H}} 0.14(\mathrm{~d}, J$ $4.4 \mathrm{~Hz}, \mathrm{H}-19 \mathrm{a})$ and 0.53 (d, J 4.4 Hz, H-19b) characteristic of a tetrasubstituted cyclopropane ring, suggesting a devadarane skeleton for $\mathbf{2}$. Like compound $\mathbf{1}$, one ABC system relative to an 1,2-glycol moiety was observed at $\delta_{\mathrm{H}} 3.32$ (dd, 1H, $\left.J 9.3,2.7 \mathrm{~Hz}, \mathrm{H}-15\right), 3.51$ (dd, 1H, $J$ 10.8, $9.3 \mathrm{~Hz}, \mathrm{H}-16 \mathrm{a}$ ) and 3.74 (dd, 1H, J 10.8, $2.7 \mathrm{~Hz}, \mathrm{H}-$ $16 \mathrm{~b})$. In addition, a deshielded signal assignable to an acetylated oxymethine hydrogen at $\delta_{\mathrm{H}} 4.82(\mathrm{dd}, J 11.1$, $5.2 \mathrm{~Hz}, \mathrm{H}-11$ ), was confirmed by the presence of a methyl group at $\delta_{\mathrm{H}} 1.99(\mathrm{~s}, \mathrm{H}-21)$. All the above observations were consistent with the cross-peak correlations observed on the ${ }^{1} \mathrm{H},{ }^{1} \mathrm{H}-\mathrm{COSY}$ experiment.

Comparative analysis of $\mathrm{BB}$ and DEPT $-{ }^{13} \mathrm{C}$ NMR (Table 1) spectra revealed 22 signals. From these data one can easily deduce the presence of three oxygen bearing saturated carbons at $\delta_{\mathrm{C}} 62.5\left(\mathrm{CH}_{2}\right), 78.2(\mathrm{CH})$ and $80.6(\mathrm{CH})$, and 18 other $\mathrm{sp}^{3}$ not functionalized carbon signals (4 methyls, 8 methylenes, 2 methines and 4 quaternaries), in addition of a characteristic carbonyl of an ester function at $\delta_{\mathrm{C}}$ 162.5. Carbonyl carbons of acetate derivatives of alcohols usually appear around $170 \mathrm{ppm}$, thus the relative shielding of the acetate carbonyl $(\Delta \delta \sim 8.0 \mathrm{ppm})$ may indicates stereochemical implications related to positioning either as $\alpha$-equatorial or $\beta$-axial as observed for other devadarane diterpenoids. ${ }^{12}$ The unambiguous assignment of all carbon and hydrogens was possible for the HMQC spectrum analysis (Table 1).

Besides the other NMR data already discussed, further evidences of a devadarane skeleton merged from the observed long-range correlations in the HMBC spectrum. In this experiment were observed correlation signals between hydrogens of the cyclopropane moiety at $\delta_{\mathrm{H}} 0.14$ and $0.53(2 \mathrm{H}-19)$ with carbons at $\delta_{\mathrm{C}} 22.6(\mathrm{C}-$ 18), 33.9 (C-3) and 50.3 (C-10). Like compound 1, correlations of the oxymethine hydrogen at $\delta_{\mathrm{H}} 3.32(\mathrm{H}-$ $15)$ with the carbons at $\delta_{\mathrm{C}} 19.7(\mathrm{C}-17), 35.2$ (C-14) and 36.6 (C-12) confirmed the position of the ethyl 1,2-glycol system at C-13 and provided additional proof for the suggested structure. The acetyl group at C-11 was confirmed due to the correlation of the oxymethine hydrogen at $\delta_{\mathrm{H}} 4.82(\mathrm{H}-11)$ with the carbons at $\delta_{\mathrm{C}} 7.7$ (C-20) and 50.3 (C-10) and 162.5 (C-22). The shielding effect observed for the ${ }^{13} \mathrm{C}$ NMR signal of the C-20 methyl group at $\delta_{\mathrm{C}} 7.7$, when compared with related devadarane diterpenoids $\left(\sim \delta_{\mathrm{C}} 12.0\right),{ }^{10}$ is attributed to a $\gamma$-gauche shielding effect due the presence of the 
Table 1. ${ }^{1} \mathrm{H}$ and ${ }^{13} \mathrm{C}$ NMR data for compounds $\mathbf{1 ,}, \mathbf{2}, 4$ and $5\left(\mathrm{CDCl}_{3}\right)$

\begin{tabular}{|c|c|c|c|c|c|c|}
\hline \multirow[t]{2}{*}{ Carbon } & \multicolumn{2}{|l|}{${ }^{1} \mathrm{H}$ NMR } & \multicolumn{4}{|c|}{${ }^{13} \mathrm{C}$ NMR } \\
\hline & $\mathbf{1}^{\mathrm{a}}$ & $2^{\mathrm{a}}$ & $1^{a}$ & $2^{\mathrm{a}}$ & $4^{\mathrm{b}}$ & $5^{b}$ \\
\hline 1 & & 1.29 & 212.6 & 22.8 & 25.0 & 23.2 \\
\hline \multirow{2}{*}{2} & 2.39 & 1.31 & 42.6 & 28.1 & 29.6 & 19.6 \\
\hline & & 1.58 & & & & \\
\hline 3 & 1.48 & 1.28 & 44.2 & 33.9 & 35.4 & 32.2 \\
\hline 4 & & & 44.2 & 17.8 & 18.8 & 16.7 \\
\hline 5 & & & 71.2 & 25.8 & 27.7 & 25.2 \\
\hline \multirow[t]{2}{*}{6} & 1.40 & 0.86 & 24.2 & 32.5 & 33.3 & 43.4 \\
\hline & 1.09 & 1.60 & & & & \\
\hline \multirow[t]{2}{*}{7} & 1.70 & 0.92 & 22.6 & 23.7 & 24.5 & 69.6 \\
\hline & 1.20 & 1.59 & & & & \\
\hline 8 & 1.86 & 1.45 & 40.2 & 40.9 & 42.5 & 48.5 \\
\hline 9 & & & 42.0 & 43.1 & 45.6 & 38.7 \\
\hline 10 & 2.05 & 1.49 & 62.8 & 50.3 & 52.5 & 49.8 \\
\hline \multirow[t]{2}{*}{11} & 1.67 & $4.82(\mathrm{dd}, J 11.1,5.2 \mathrm{~Hz})$ & 33.9 & 78.2 & 76.8 & 34.0 \\
\hline & 1.42 & & & & & \\
\hline \multirow[t]{2}{*}{12} & 1.40 & 1.59 & 28.5 & 36.6 & 41.1 & 31.2 \\
\hline & 1.08 & & & & & \\
\hline 13 & & & 36.8 & 37.4 & 38.8 & 36.5 \\
\hline \multirow[t]{2}{*}{14} & 1.40 & 1.59 & 36.3 & 35.2 & 38.1 & 28.8 \\
\hline & 1.04 & & & & & \\
\hline 15 & $3.34(\mathrm{dd}, J 9.4,2.9 \mathrm{~Hz})$ & $3.32(\mathrm{dd}, J 9.3,2.7 \mathrm{~Hz})$ & 80.9 & 80.6 & 82.4 & 81.9 \\
\hline \multirow[t]{2}{*}{16} & $3.76(\mathrm{dd}, J 10.7,2.9 \mathrm{~Hz})$ & $3.51(\mathrm{dd}, J 10.8 .9 .3 \mathrm{~Hz})$ & 62.7 & 62.5 & 63.6 & 62.6 \\
\hline & $3.54(\mathrm{dd}, J 10.7,9.4 \mathrm{~Hz})$ & $3.74(\mathrm{dd}, J 10.8,2.7 \mathrm{~Hz})$ & & & & \\
\hline 17 & $1.00(\mathrm{~s})$ & $1.03(\mathrm{~s})$ & 18.9 & 19.7 & 20.3 & 18.1 \\
\hline 18 & $1.18(\mathrm{~s})$ & $1.03(\mathrm{~s})$ & 29.3 & 22.6 & 23.3 & 21.7 \\
\hline \multirow[t]{2}{*}{19} & $1.18(\mathrm{~s})$ & $0.14(\mathrm{~d}, J 4.4 \mathrm{~Hz})$ & 29.5 & 25.2 & 26.0 & 24.5 \\
\hline & & $0.53(\mathrm{~d}, J 4.4 \mathrm{~Hz})$ & & & & \\
\hline 20 & $0.58(\mathrm{~s})$ & $0.94(\mathrm{~s})$ & 11.9 & 7.7 & 7.1 & 12.2 \\
\hline 21 & & $1.99(\mathrm{~s})$ & & 22.0 & & \\
\hline 22 & & & & 162.5 & & \\
\hline
\end{tabular}

a300/75 MHz; '500/125 MHz.

equatorial oxy group at $\mathrm{C}-11$. On the basis of biogenetic arguments, along with the knowledge of occurrence of ent-devadarane diterpenoids only in Erythroxylum spp., we can suggest that compound $\mathbf{2}$ also belongs to the enantio series. From the foregoing evidence, compound 2 was identified as the new natural $\alpha$-acetoxy-

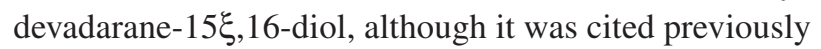
in the literature as the chemical derivative of compound $\mathbf{4},{ }^{12}$ this paper comprises the first report of $\mathbf{2}$ as a natural product.

The NOESY experiment was an important tool to reach the final relative stereochemistry of compound $\mathbf{5}$. In particular, the orientation of the H-7 was determined to be axial, as revealed by the diagnostic NOE crosspeak for the hydrogen $\mathrm{H}-7$ at $\delta_{\mathrm{H}} 3.42$ with the $\mathrm{CH}_{3}-20$ at $\delta_{\mathrm{H}} 0.81$. This was in agreement with the relative stereochemistry already reported for hydroxydevadarool, isolated previously from Erythroxylum monogynum. ${ }^{13}$

Up to now the occurrence of devadarane diterpenoids in higher plants is restricted to species of the Erythroxylum genus. Their presence is remarkable and the potential as chemical markers was already discussed. ${ }^{13}$ Physical and spectroscopic data comparison of compounds $\mathbf{3}, \mathbf{4}$, and $\mathbf{5}$ with those from literature made

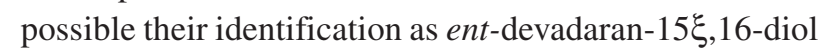
(erythroxydiol X), ${ }^{10}$ ent-devadaran- $11 \alpha, 15 \xi, 16$-triol (erythroxytriol Q) ${ }^{12}$ and ent-devadaran-7 $\beta, 15 \xi, 16$-triol (hydroxydevadarool), ${ }^{13}$ respectively. To the best of our acknowledge this is the first report of compounds $\mathbf{4}$ and $5{ }^{13} \mathrm{C}$ NMR spectroscopic data.

None of the isolated diterpenes (1-5) showed any cytotoxicity activity against five tumor cell lines: two human leukemias (HL-60 and CEM), human breast adenocarcinoma (MCF-7), human colon adenocarcinoma (HCT-8) and murine melanoma (B16).

\section{Experimental}

\section{General procedures}

Melting points were obtained on a Mettler FP82HT apparatus and are uncorrected. IR spectra were recorded 
using a Perkin Elmer 1000 spectrophotometer. Optical rotations were measured on a Perkin Elmer 341 polarimeter. Mass spectra were obtained on a Hewlett-Packard 5971 mass spectrometer by electron impact ionization $(70 \mathrm{eV})$. ${ }^{1} \mathrm{H}$ and ${ }^{13} \mathrm{C}$ NMR where recorded on a Bruker Avance DRX500 or DPX-300 instruments. All compounds were visualized on TLC using the vanillin-sulfuric acid reagent.

\section{Plant material}

Roots and trunk heartwood of Erythroxylum barbatum O. E. Schulz were collected in August 2002, in Acarape County, Ceará State, Northeast of Brazil. The plant material was identified by Dr. Edson Paula Nunes of the Herbário Prisco Bezerra (EAC), Departamento de Biologia, Universidade Federal do Ceará, Brazil, where the voucher specimen (No. 28815) was deposited.

\section{Extraction and isolation}

Roots $(1.7 \mathrm{~kg})$ and trunk heartwood $(3.3 \mathrm{~kg})$ of $E$. barbatum were separately pulverized and extracted with hexane at room temperature. Both plant residues from the hexane extraction were extracted with ethanol. All the solvents were removed under reduced pressure to give the correspondent extracts.

The EtOH extract $(30.0 \mathrm{~g})$ from roots was dissolved in a mixture of $\mathrm{MeOH}: \mathrm{H}_{2} \mathrm{O} 1: 1$ and submitted to partition successively with hexane, $\mathrm{CHCl}_{3}$, EtOAc and $\mathrm{MeOH}$. The $\mathrm{CHCl}_{3}$ fraction $(7.0 \mathrm{~g})$ was submitted to silica gel flash chromatography using $\mathrm{CHCl}_{3}$ and EtOAc as binary mixtures with increasing polarity, to give several fractions which were combined according to TLC analysis. Fraction 23 (1.2 g) was further purified over Sephadex LH-20 by elution with $\mathrm{MeOH}$ to afford compound 1 (13.0 mg). Coarse chromatography on a silica gel column of the hexane extract $(3.2 \mathrm{~g})$ by elution with hexane, $\mathrm{CH}_{2} \mathrm{Cl}_{2}$, EtOAc and $\mathrm{MeOH}$ yielded the correspondent fractions. The EtOAc fraction $(0.8 \mathrm{~g})$ was further purified over Sephadex LH-20 by elution with $\mathrm{MeOH}$ to furnished 15 fractions. Successive flash chromatography of fraction 5-11 furnished the pure compounds 2 (16.2 mg), 3 (4.0 mg) and procesterol (9.7 mg).

The EtOH extract of the trunk heartwood $(75.9 \mathrm{~g}$ ) was coarsely fractionated on a silica gel column by elution with hexane, $\mathrm{CHCl}_{3}$ and EtOAc. Isocratic silica gel flash chromatography of the EtOAc fraction $(5.3 \mathrm{~g})$ using $\mathrm{CHCl}_{3}$ :EtOAc (1:1) as eluent afforded compounds 4 (14.9 $\mathrm{mg}), 5(11.6 \mathrm{mg}), \beta$-sitosterol $(10.5 \mathrm{mg})$ and $\beta$-sitosterol glucoside $(49.8 \mathrm{mg})$.
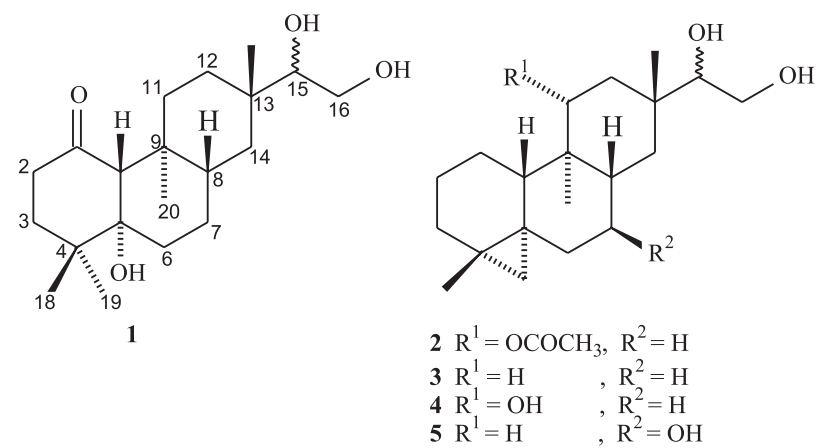

Ent-Rosan-1-one-5 $\alpha, 15 \xi, 16-$ triol (1)

Colorless resin. $[\alpha]_{\mathrm{D}}^{20}:-15^{\circ}\left(\mathrm{CHCl}_{3} ; c 0.16\right)$. IR (film) $v_{\max } / \mathrm{cm}^{-1}: 3421,2933,2867,1708,1463,1340,1257$, 1026, 756. EIMS $\mathrm{m} / \mathrm{z}$ (rel. int.): $338\left[\mathrm{M}^{+}\right]$(absent), 320 (3), 304 (20), 243 (23), 199 (20), 187 (23), 149 (25), 135 (51), 121 (58), 109 (62), 95 (100), 81 (75), 57 (72), 55 (98). ${ }^{1} \mathrm{H}$ and ${ }^{13} \mathrm{C}$ NMR data: see Table 1.

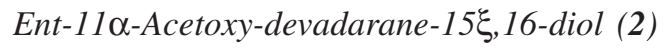

White amorphous solid. $[\alpha]_{\mathrm{D}}^{20}:-16.0^{\circ}\left(\mathrm{CHCl}_{3} ; c 0.26\right)$. IR (film) $v_{\max } / \mathrm{cm}^{-1}: 3456,2929,2862,1724,1657,1459$, 1377, 1249, 1377, 1249, 1174, 1024, 975. EIMS m/z (rel. int.): $364\left[\mathrm{M}^{++}\right](2), 322(2), 304$ (10), 261 (7), 243 (34), 187 (17), 173 (15), 161 (18), 149 (55), 133 (32), 119 (49), 107 (48), 95 (71), 81 (69), 57 (79), 55 (100). ${ }^{1} \mathrm{H}$ and ${ }^{13} \mathrm{C}$ NMR: see Table 1.

\section{Acknowledgments}

The authors are grateful to CNPq, CAPES, PADCT, PRONEX, FUNCAP, FINEP for the fellowships and financial support.

\section{Supplementary Information}

Supplementary data for compounds $\mathbf{1}$ and $\mathbf{2}$ are available free of charge at http://jbcs.org.br, as PDF file.

\section{References}

1. Griffin, W. J.; Lin, G. D.; Phytochemistry 2000, 53, 623.

2. Bohm, A. F.; Loo, T.; Nicholls, K. W.; Plowman, T.; Phytochemistry 1988, 27, 833.

3. Jonhson E.; Schmidt, W. F.; Norma, H. A.; Biochem. Syst. Ecol. 1998, 26, 743.

4. Inigo, R. P. A.; Pomilio, A. B.; Phytochemistry 1985, 24, 347.

5. Kapadi, A. H.; Soman, R.; Sobti, R. R.; Dev, S.; Indian J. Chem., Sect B 1983, 22, 964. 
6. Soman, R.; Dev, S.; Indian J. Chem., Sect B 1983, 22, 978.

7. Ansell, S. M.; Pegel, K. H.; Taylor, D. A. H.; Phytochemistry 1993, 32, 937.

8. Plowman, T.; Adv. Econ. Bot. 1984, 1, 62.

9. Schulz, O. E.; A. Pflanzer 1907, 134 (Heft29), 101

10. Santos, C. C.; Lima, M. A. S.; Silveira, E. R.; Biochem. Syst. Ecol. 2003, 31, 661.

11. Santos, C. C.; Lima, M. A. S.; Braz-Filho, R.; Simone, C. A.; Silveira, E. R.; Magn. Reson. Chem. 2005, 43, 1012.
12. Connolly, J. D.; Gunn, D. M.; McCrindle, R.; Murray, R. D. H.; Overton, K. H.; J. Chem. Soc. (C) 1967, 668.

13. Soman, R.; Dev, S.; Misra, R.; Pandey, R. C.; Tetrahedron Lett. 1964, 49, 3767.

14. Dev, S.; Pure Appl. Chem. 1979, 51, 837.

Received: December 28, 2005 Published on the web: August 30, 2006 


\section{Diterpenes from Erythroxylum barbatum}

Cláudio C. dos Santos, ${ }^{a}$ Mary Anne S. Lima, ${ }^{*, a}$ Raimundo Braz Filho ${ }^{b}$ and Edilberto R. Silveira ${ }^{a}$

${ }^{a}$ Curso de Pós-Graduação em Química Orgânica, Departamento de Química Orgânica e Inorgânica, Universidade Federal do Ceará, CP 12.200, 60455-760 Fortaleza-CE, Brazil

${ }^{b}$ Setor de Química de Produtos Naturais, Universidade Estadual do Norte Fluminense, 28013-600 Campos-RJ, Brazil

s
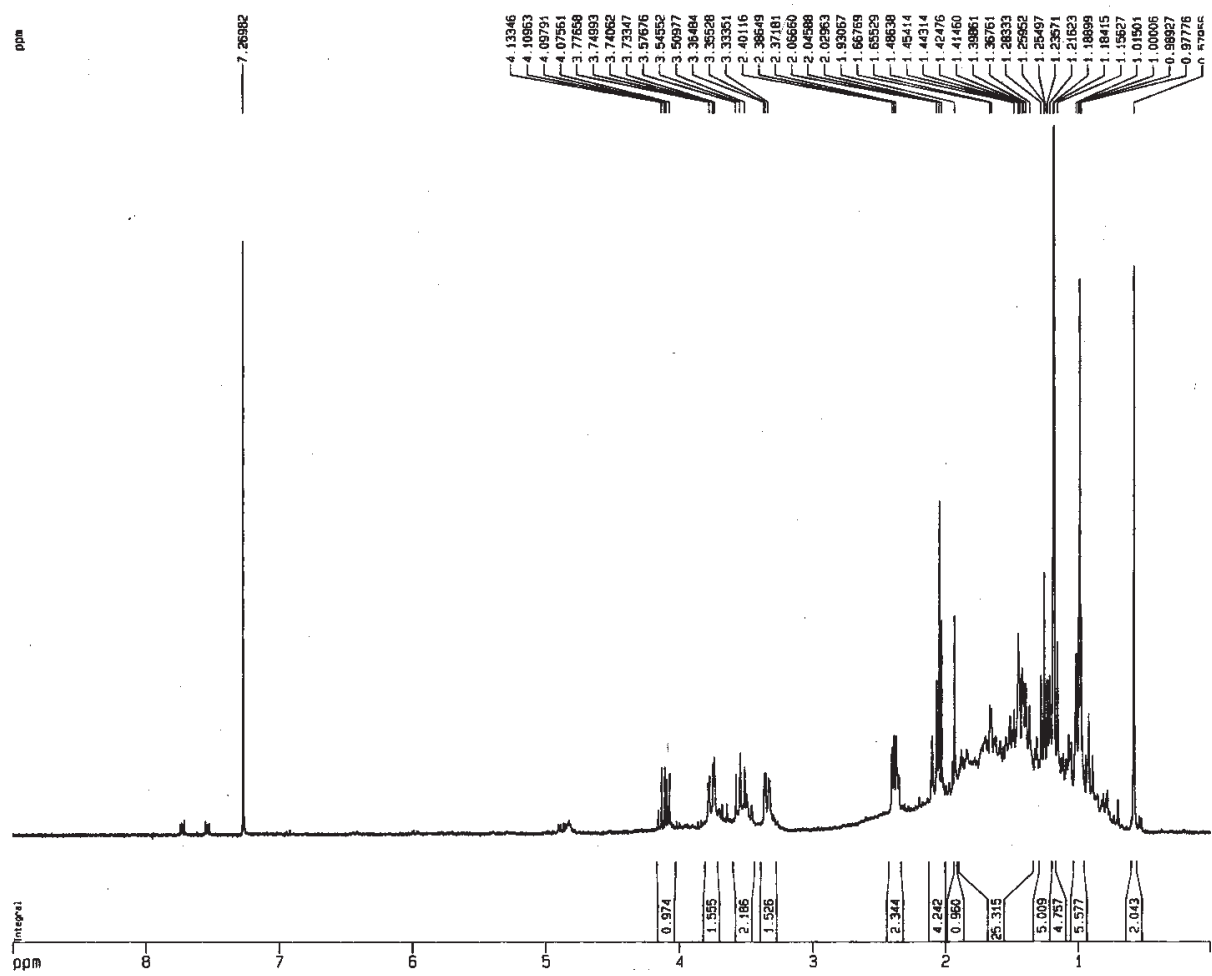

Figure S1. ${ }^{1} \mathrm{H}$ NMR spectrum $\left(\mathrm{CDCl}_{3}, 300 \mathrm{MHz}\right)$ of compound $\mathbf{1}$. 


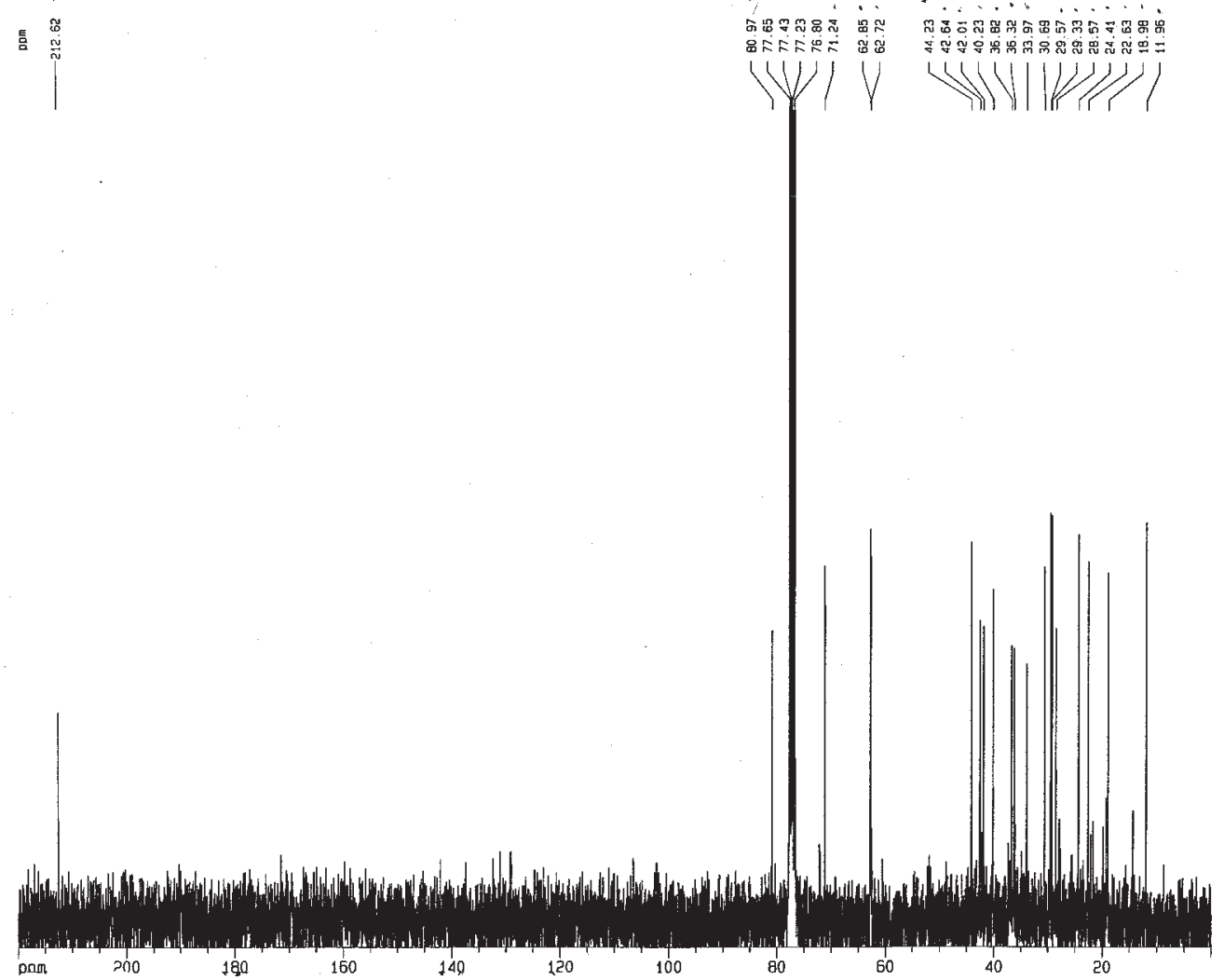

Figure S2. ${ }^{13} \mathrm{C}$ NMR spectrum $\left(\mathrm{CDCl}_{3}, 75 \mathrm{MHz}\right)$ of compound $\mathbf{1}$.

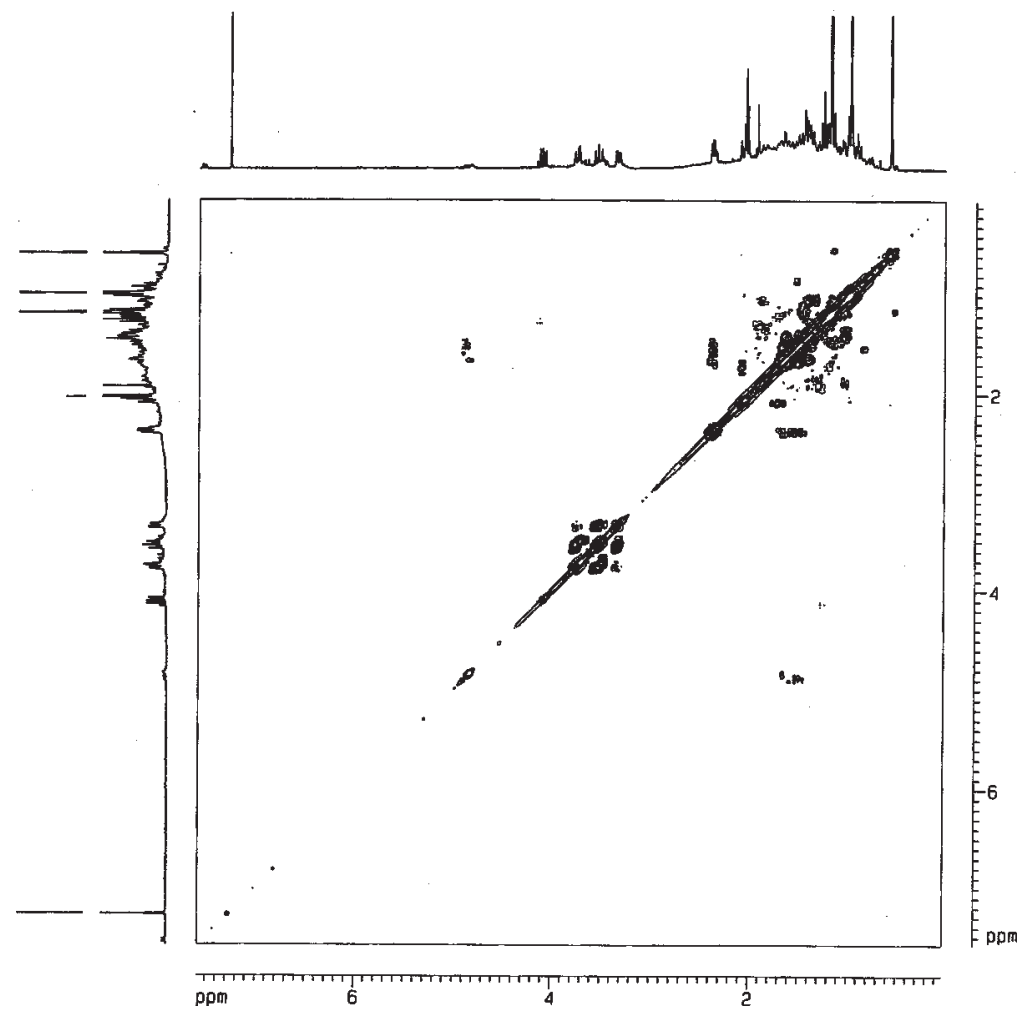

Figure S3. gCOSY NMR experiment $\left(\mathrm{CDCl}_{3}, 300 \mathrm{MHz}\right)$ of compound $\mathbf{1}$. 

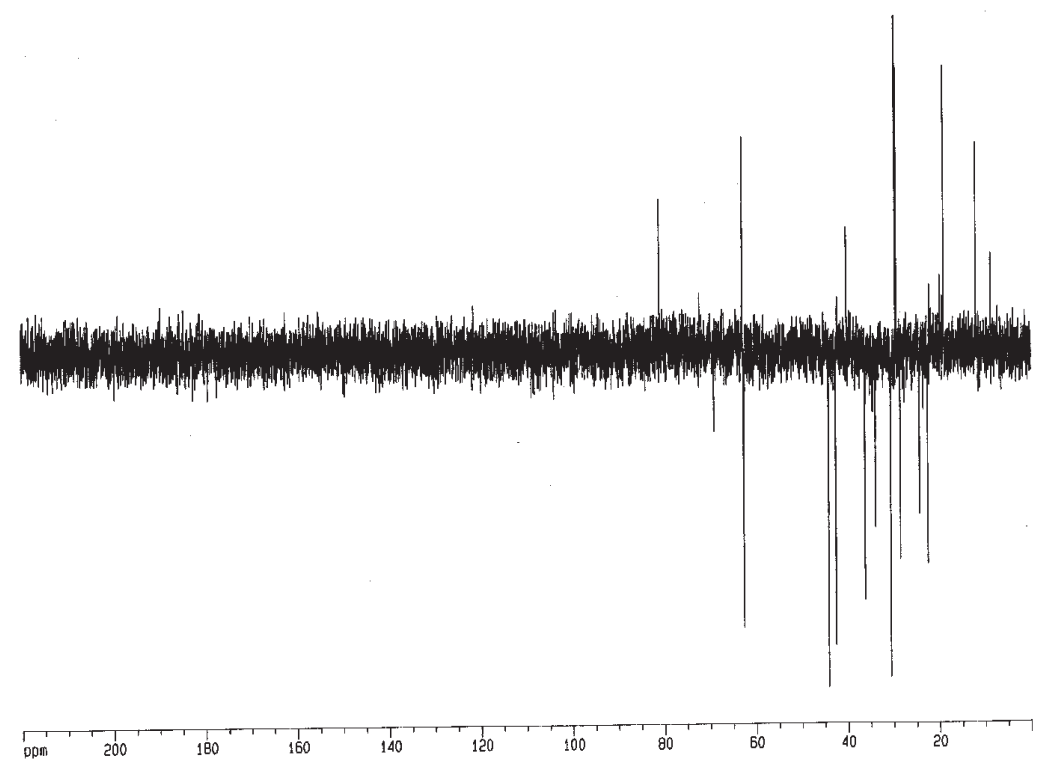

Figure S4. DEPT NMR experiment $\left(\mathrm{CDCl}_{3}, \mathrm{MHz}\right)$ of compound $\mathbf{1}$.

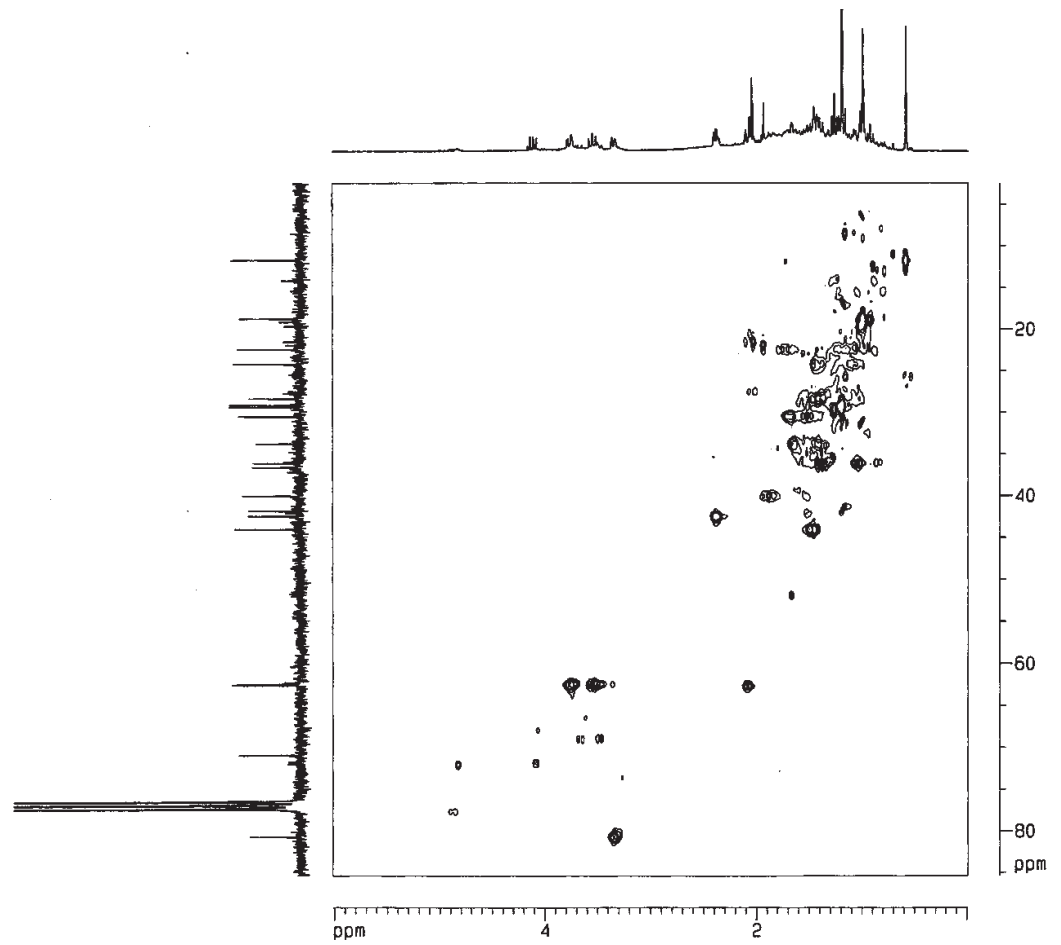

Figure S5. HSQC NMR experiment of compound 1. 


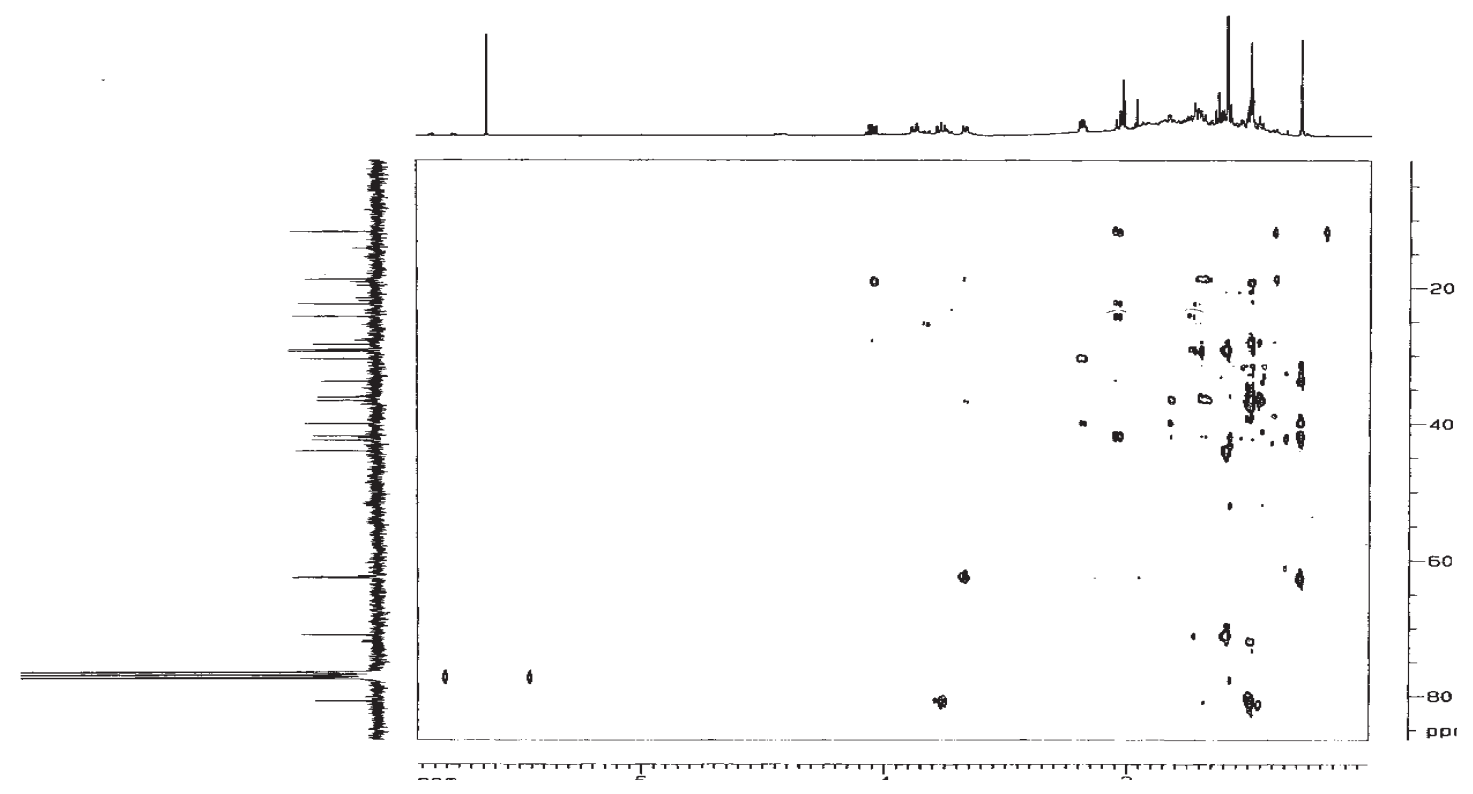

Figure S6. HMBC NMR experiment of compound 1.

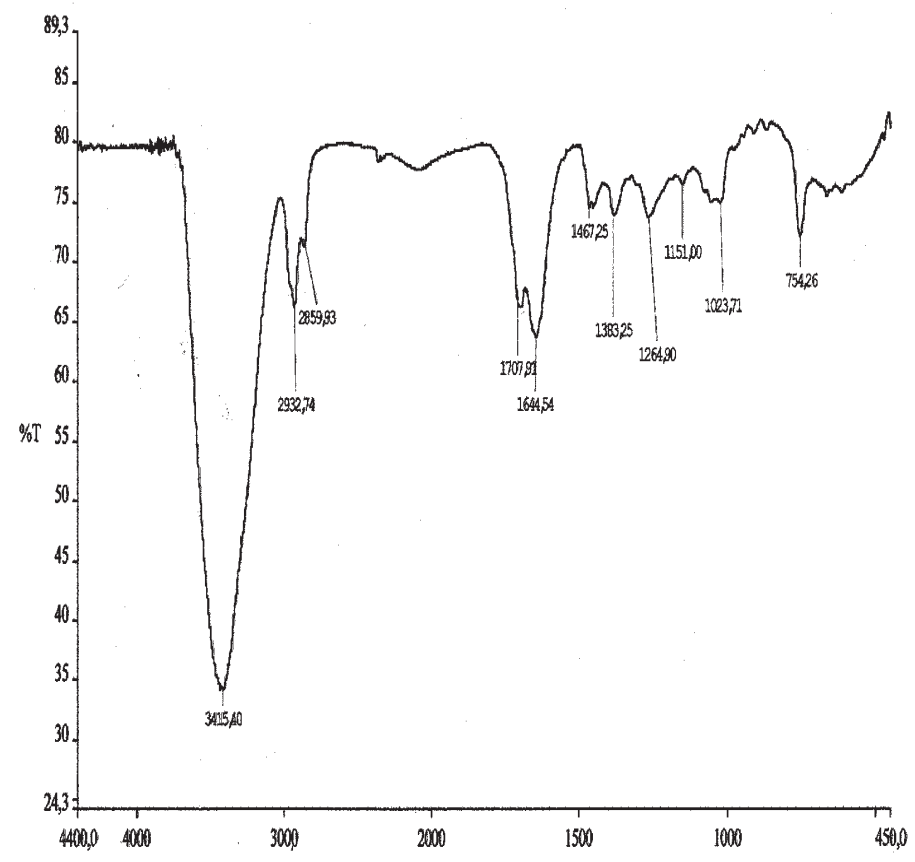

Figure S7. IV spectrum of compound $\mathbf{1}$. 


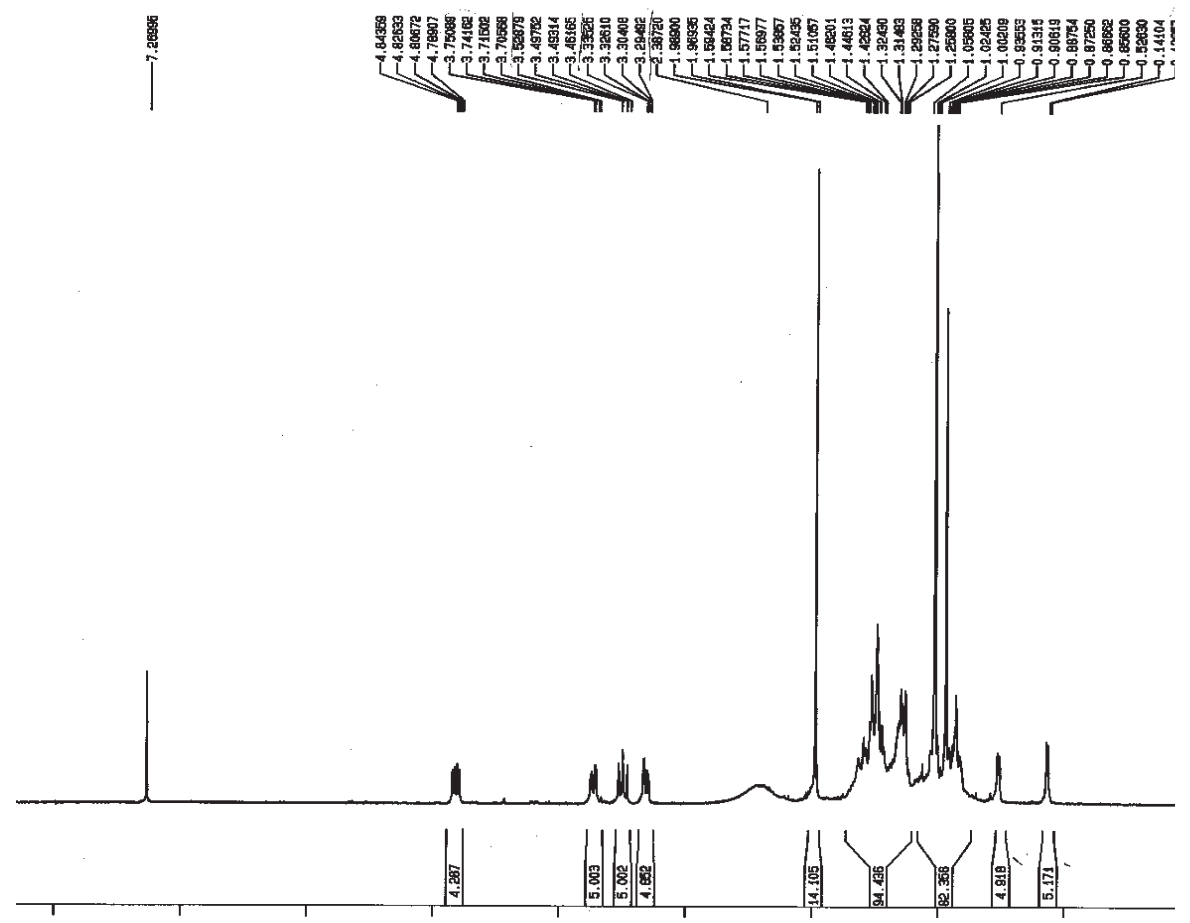

Figure S8. ${ }^{1} \mathrm{H}$ NMR spectrum $\left(\mathrm{CDCl}_{3}, 300 \mathrm{MHz}\right)$ of compound 2.

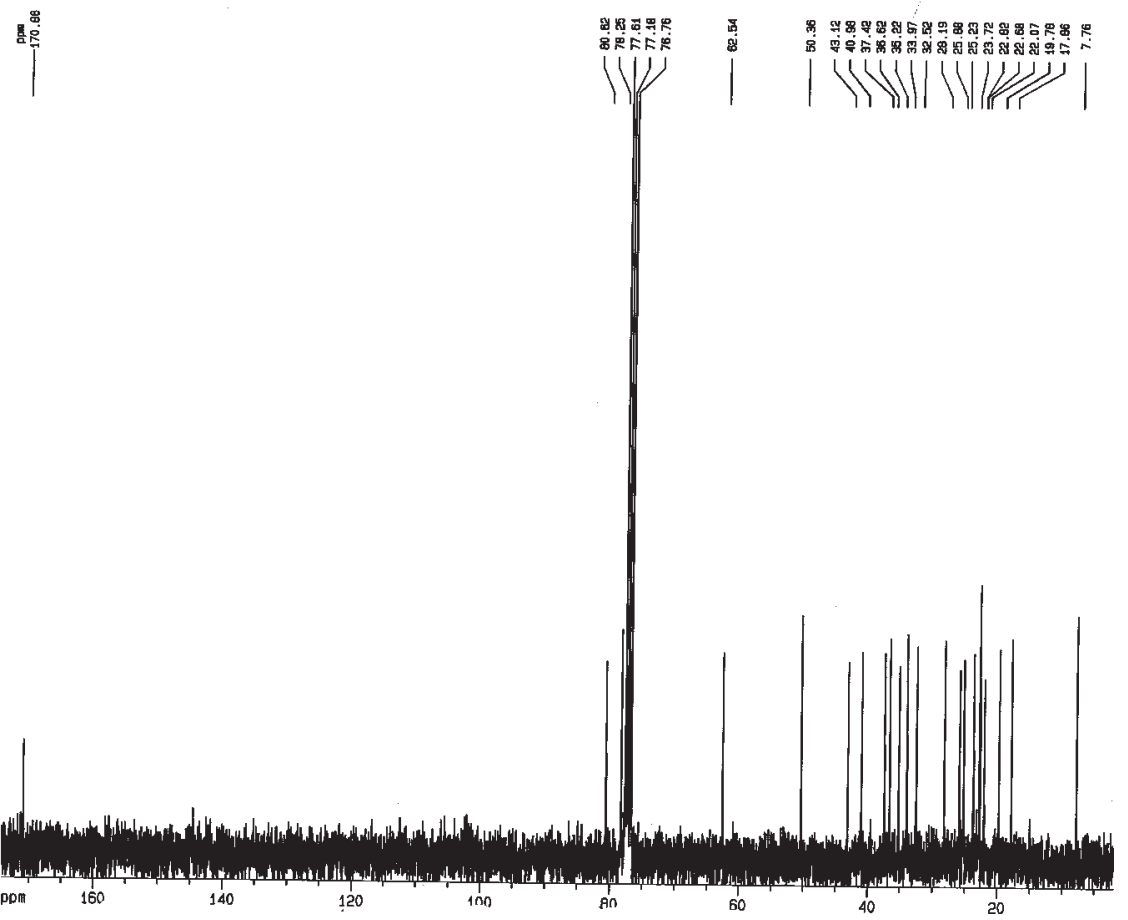

Figure S9. ${ }^{13} \mathrm{C}$ NMR spectrum $\left(\mathrm{CDCl}_{3}, 75 \mathrm{MHz}\right)$ of compound 2. 

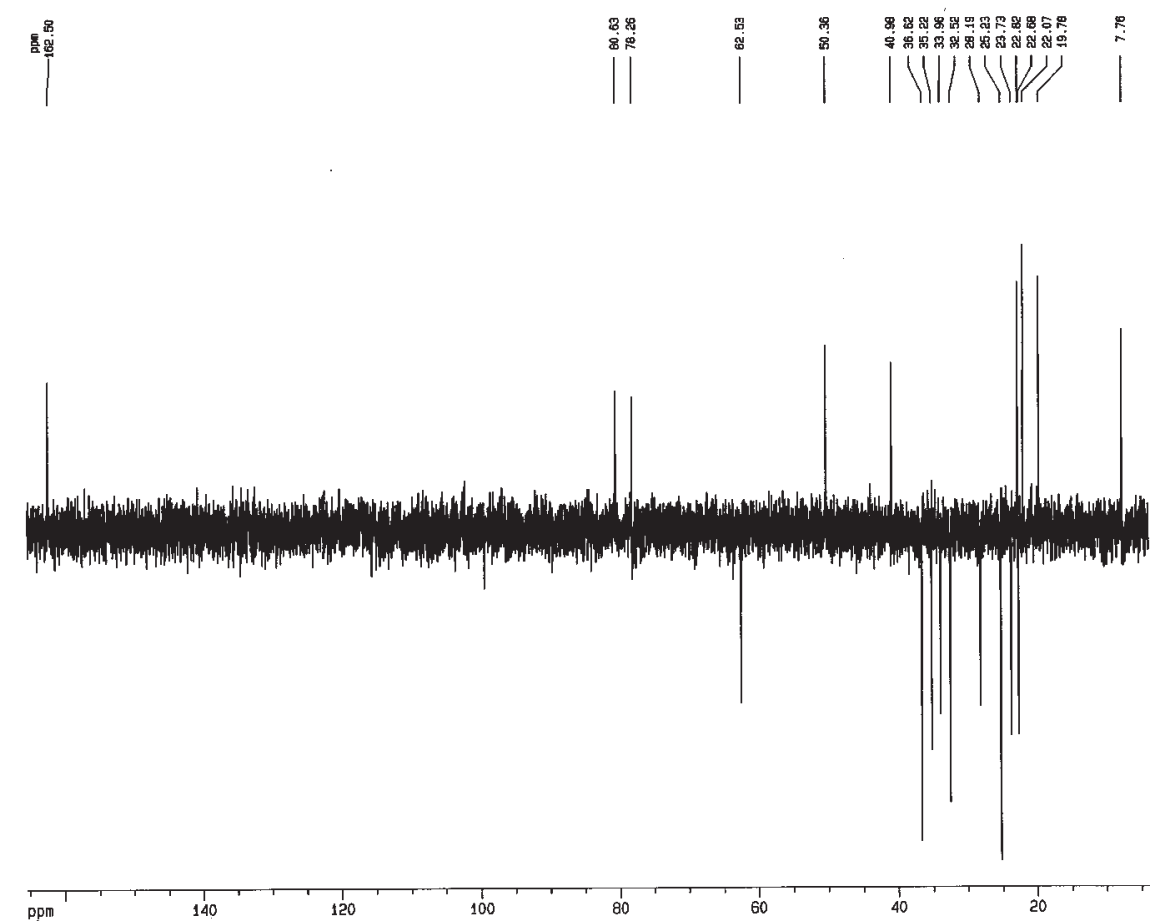

Figure S10. ${ }^{13} \mathrm{C}$ NMR spectrum $\left(75 \mathrm{MHz}, \mathrm{CDCl}_{3}\right)$ of compound 2 .

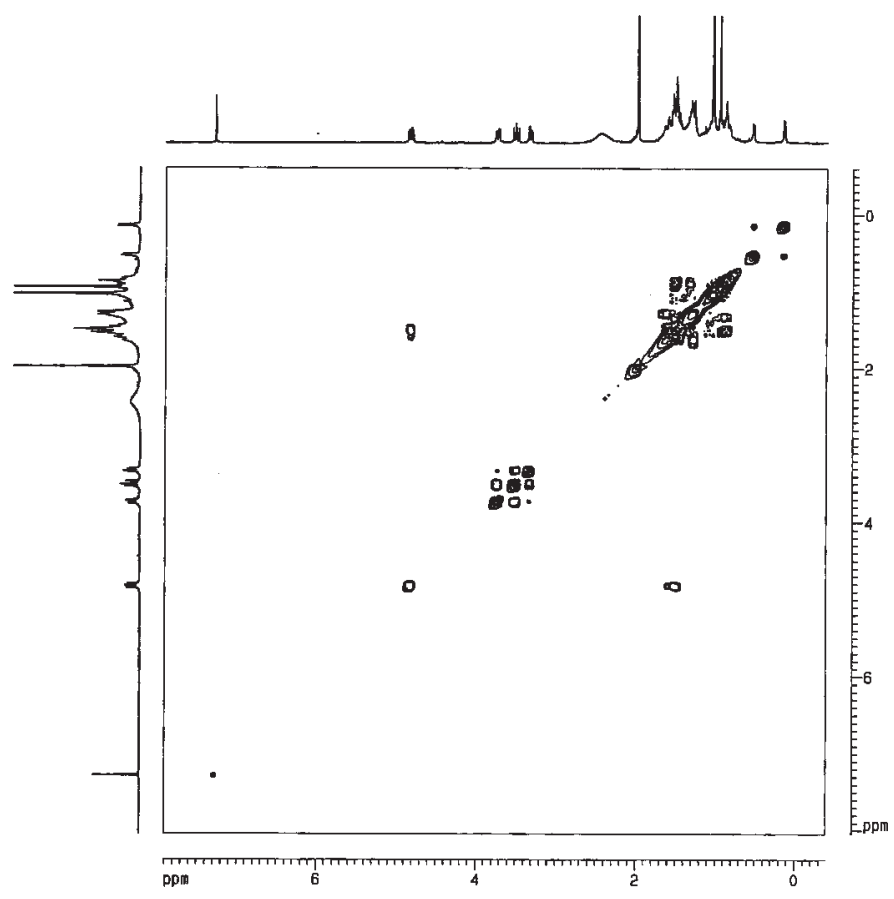

Figure S11. gCOSY NMR experiment of compound 2. 


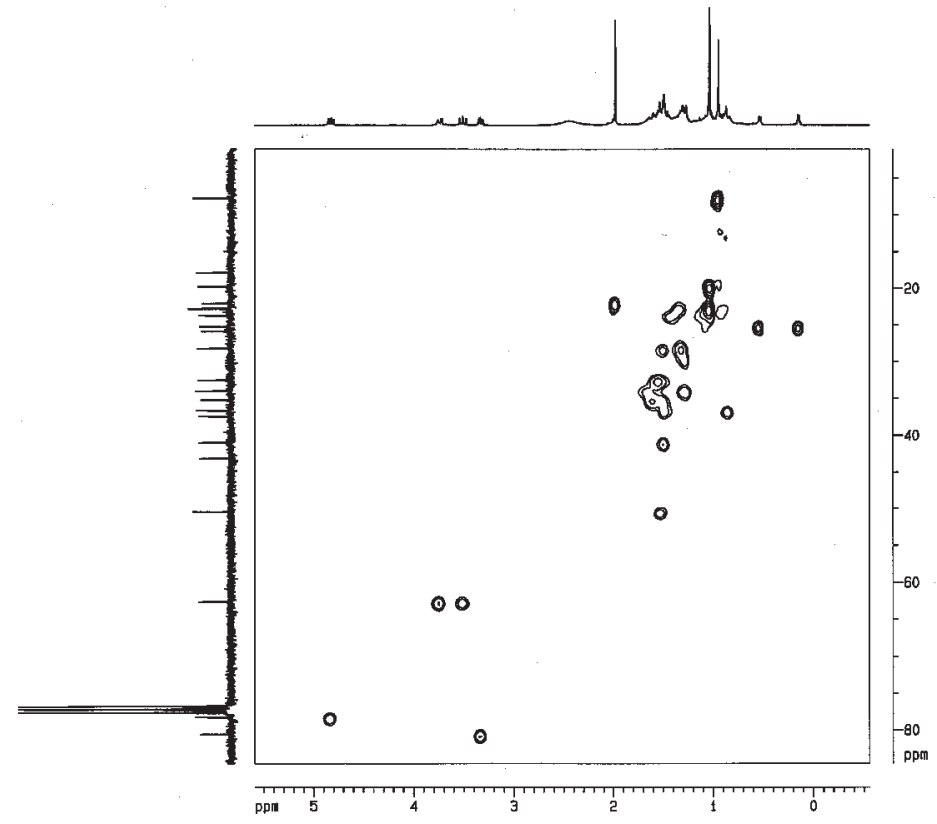

Figure S12. HSQC NMR experiment of compound 2.

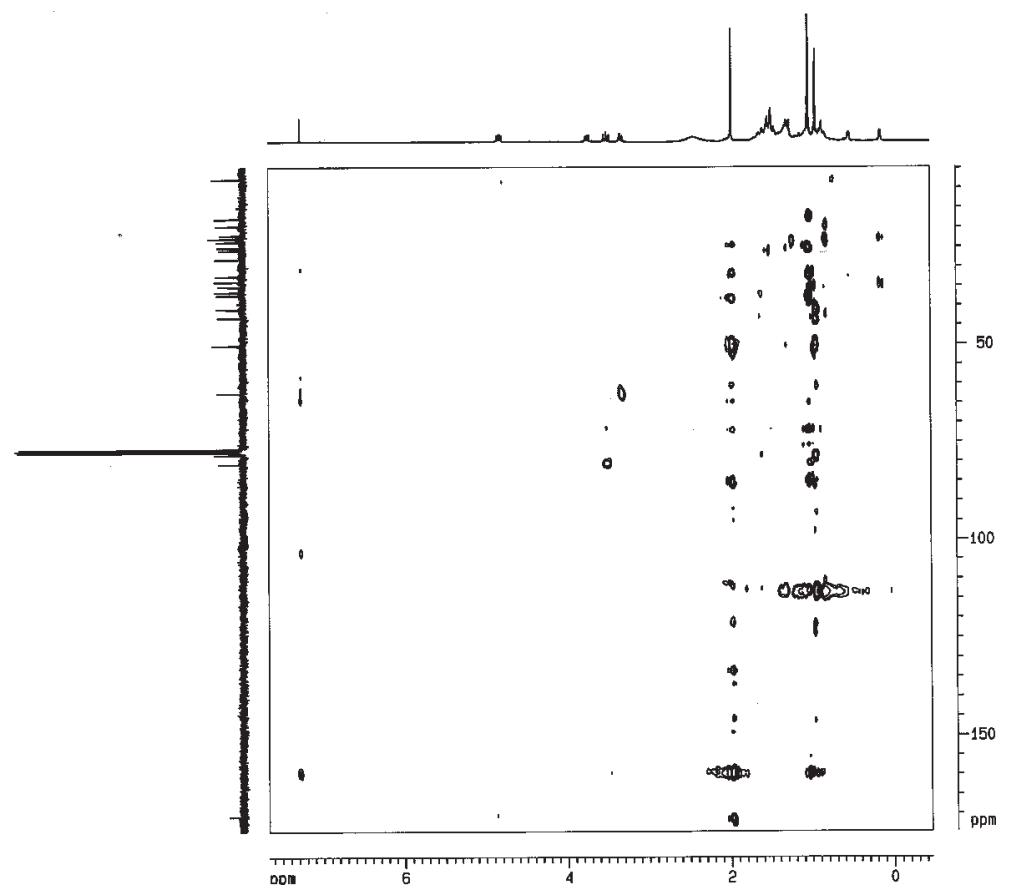

Figure S13. HMBC NMR experiment of compound 2. 